\title{
Empowerment of Integrated Health Post Cadres through Fish Nugget Processing to Prevent Anemia in Pregnant Women
}

\author{
Awatiful Azza ${ }^{1 *}$, Danu Indra Wardhana ${ }^{2}$ \\ ${ }^{1,2}$ Faculty of Health Science University of Muhammadiyah Jember, Karimata Street on 49, Jember \\ *E-mail: awatiful.azza@unmuhjember.ac.id
}

Submitted Article :Agustus 8, 2021

Review article :Agustus 15, 2021

Accepted article :Agustus 18, 2021

\begin{abstract}
Fish is a source of nutrition that is cheap and easy to get, especially in Jember Regency. One of the health problems experienced by teenage girls and pregnant women is anemia. Anemia can be prevented by consuming adequate and diverse nutrients. However, the society at Darungan Dusun (Dusun is lower than the village in Indonesia's administrational hierarchy) did not know how to make exciting and not boring processed food. Fish nugget is creations from tuna or catfish to increase fish consumption coverage in society. This activity was carried out in the Integrated Health Post at Darungan Dusun Kemuning Lor Village, Jember Regency. There were fourteen of the integrated health post cadres and pregnant women who participated in this activity. Community service methods used demonstrations and counseling. The counseling and demonstration of fish nugget processing improve knowledge in Integrated Health Post cadres and pregnant women. Furthermore, it can prevent anemia in pregnant women. There should be support and participation from the local government for the sustainability of this activity.
\end{abstract}

Keywords: Empowerment; Integrated Health Post; Cadres; Fish Nugget Processing; Anemia; Pregnant Women

\section{INTRODUCTION}

Pregnancy is a physiological condition in women after fertilization (Ho, Flynn, and Pasupathy, 2016). A good pregnancy is a pregnancy that grows and develops without being accompanied by certain complications or diseases (Koenig, 2017). So, pregnant women must receive supervision during their pregnancy to avoid complications (Gebreweld and Tsegaye, 2018). One of the complications in pregnant women is anemia (Kamaruddin, Karlina, and Nurhayani, 2019). Anemia usually correlates with the nutritional status of pregnant women (Kamaruddin et al., 2019).

The Integrated Health Post (posyandu) is a primary level service that becomes a reference for mothers in the community. It is an essential service as a community-based health effort best known in the community. It organizes at most minuscule five priority programs: maternal and child health, family planning, nutrition improvement, immunization, and diarrhea control. The percentage of the active cadre is one indicator that shows the participation and independence of the community in overcoming health problems that arise in its area. Didah (2020) explains that the existence of the Integrated Health Post cadres is essential in the promotive and preventive efforts to the community, especially related to the nutritional status of the community as well as maternal and child health efforts to help reduce the increase in maternal and infant mortality.

Integrated Health Post Cadres are movers in the integrated healthcare center playing an active role in mobilizing the community and helping to improve health status. According to Suhat and Hasanah (2014), the Integrated Health Post is very dependent on the cadres' role, who generally volunteers from the community. Cadres are selected from community members who have more abilities than others. One of the cadres' duties in the Integrated Health Post activities is to assist health workers in improving the health of pregnant women through examinations and counseling. Septiyaningsih et al. (2020) explain that cadres can provide motivation through Fish Nugget Processing to Prevent Anemia in Pregnant Women 
or even education for high-risk pregnant women to routinely carry out routine pregnancy checks. Anemia is one of the complications of pregnancy that can occur at all levels of society. According to Nisa et al. (2019), it is a nutritional problem globally, especially in developing countries. Cadres should provide alternative solutions to this problem through modification in dietary habits. In many areas of Indonesia, pregnant women tend to consume less fish-based foodstuffs. This suboptimal consumption behavior of fish-based nutrients can result in an unbalanced nutritional intake (Hidayat, Maimun, and Sukarno, 2020). Meanwhile, all nutritional elements must be balanced during pregnancy, including folic acid, minerals, and iron (Nafsiyah, Nurilmala, and Abdullah, 2018). Malnutrition risks family nutrition, especially for adolescent girls and pregnant women (Zulhaida Lubis et al., 2017). It is due to a lack of knowledge about nutrition in pregnancy (Kamaruddin, Jusni, and Amalia Sari, 2019). One of the risks caused by not meeting complete nutritional elements is anemia (Gebreweld and Tsegaye, 2018). Fish contains nutrients that the body needs to prevent anemia (Oh, Keats and Bhutta, 2020).

\section{GENERAL DESCRIPTION OF THE COMMUNITY, PROBLEMS, AND TARGET SOLUTIONS}

\section{General Description}

Partners in this paper were Integrated Health Post cadres at Darungan Dusun (Dusun is lower than the village in Indonesia's administrational hierarchy), Kemuning Lor village, Arjasa District. The number of active Integrated Healthcare Post at Kemuning Lor Village is eleven posyandu spreading over four Dusun; two posyandu at Krajan Dusun, two at Kopang Kebun Dusun, three at Darungan Dusun, and five at Rayap Dusun. Each integrated healthcare post has five cadres (Badan Pusat Statistik, 2018). The posyandu is carried out once a month with work programs including health services for pregnant women, immunization, toddlers growth and development monitoring, family planning, premarital counseling, and Maternal and Child Health (MCH) services. Geographically, Kemuning Lor Village is an agricultural village with future natural potential for regional economic development at the village level. According to Sugiartono et al. (2020), based on the existing village potential, the economy in Kemuning Lor Village still relies on the agricultural sector as the basis for driving the regional economy. Until now, agriculture as the leading sector still has a dominant and strategic role for economic development, both as a provider of food, raw materials for processed products, increasing village and community income, and absorbing significant numbers of workers. The superior resources with economic potential are in the agriculture, plantation, and forestry fields with several products produced, including rice, coffee, corn, peanuts, cassava, dragon fruit, rambutan, durian, petai beans, avocado, sengon (Paraserianthes Falcataria L. Nielsen), ginger, and mahogany. Dewangga et al. (2020) also explain that Kemuning Lor Village is geographically located in the highlands at an altitude of 175.45 above sea level and causes people to not use fish as a daily menu in their food consumption.

\section{Problems}

The partners did not have the knowledge and skills to process food with fish-based ingredients to prevent anemia in pregnant women. Fish is a food ingredient that is easy to get, cheap, and contains a high nutritional value necessary for pregnant women. However, Cadres and pregnant women did not know about the nutrition benefits of fish to prevent anemia. In addition, they never received training or information about fish processing to become more attractive and valuable. As a result, coverage in consuming fish to fulfill daily nutrition was low. 


\section{Target Solution}

Counseling, discussion, and education entitled "anemia and its impact on the health of young and pregnant women" targeting young women, pregnant women, and posyandu cadres. In addition, there was a demonstration of processing tuna and catfish into nuggets for alternative nutrition in preventing anemia.

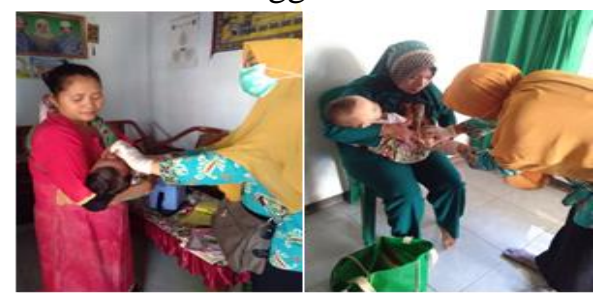

Figure 1. Activities in the Integrated Health Post at Kemuning Lor Village during the Covid-19 Pandemic

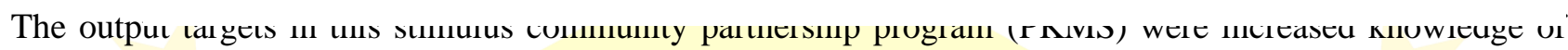
anemia risk in pregnant women and teenage girls, early detection in maternal nutritional status, nutrition fulfillment for pregnant women, and benefits of alternative nutrition based on processed fish. In addition, there were improved abilities to process food with catfish and tuna and pack processed products to keep them durable.

\section{METHOD}

The empowerment of the integrated health post cadres through processing fish nuggets did at Darungan Dusun, Kemuning Lor Village, Arjasa District, Jember Regency with direct counseling and demonstration. There were fourteen participants, consisted of the integrated health post cadres and pregnant women who participated in these activities. The implementation stages were as follows:

1.Preparation:

1) Coordinating with partners and taking permits at the auxiliary health center to access the integrated health post's activities during the covid period in Kemuning Lor village, Arjasa district, Jember regency.

2) Coordination with work teams and partners to prepare activities (schedule, place, media, and activity stages)

\section{Implementation}

The implementation of PKMS activities involved competent parties to solve problems faced by partners. The implementation team consisted of two qualified sources to transfer knowledge to partners. In addition, the team also involved two students in helping and accompanying them during activities.

3.Evaluation

1) Process:Evaluating the process of PKMS activities from beginning to end.

2) Results:Evaluating knowledge levels after PKMS activities. The knowledge included understanding nutrition to prevent anemia, the importance of nutrition for pregnant women, and fish nugget processing

3) Evaluation of the impact of activities: Observing cadres' ability to assist pregnant women in processing food to prevent anemia.

\section{RESULTS AND DISCUSSION}

Implementing the stimulus community partnership program (PKMS) focused on assisting cadres in providing counseling about nutrition for pregnant women in preventing anemia. After counseling and demonstration, we measured knowledge through questions and answers about cadres' roles and fish nugget processing. The analysis results were shown in table 1.

Table 1. Knowledge of Cadres and Pregnant Women after counseling and demonstration through Fish Nugget Processing to Prevent Anemia in Pregnant Women 


\begin{tabular}{lcc}
\hline \multicolumn{1}{c}{ Variables } & Frequency & Percentage (\%) \\
\hline Knowledge of cadres and pregnant women after counseling & 11 & 78.5 \\
Good & 3 & 21.5 \\
Enough & 0 & 0 \\
Less & 14 & 100 \\
Total & & \\
Knowledge of cadres and pregnant women after the demonstration in fish nugget & \\
processing & 9 & 64.3 \\
Good & 4 & 28.6 \\
Enough & 1 & 00.71 \\
Less & 14 & 100 \\
Total & 14 \\
\hline
\end{tabular}

Table 1. describes that cadres and pregnant women have good knowledge after counseling (78.5\%). In addition, they also have good knowledge after training in fish nugget processing (64.3\%). The activity steps were carried out as follows:

a. Preparation and licensing:

1) Coordination with the Implementation Team

A joint team from the Nursing and Agriculture study programs carried out these activities and involved students. The team coordinated to prepare this activity during the Covid period. Some agreements from coordination were: Posyandu Target, Number of Participants, Performing health protocols during the covid-19 pandemic, Activity time, Preparation for counseling and demonstration

2) Coordination with the place of implementation

We coordinated with the regional midwife at the Kemuning Lor village public health center (PHC). Then, we agreed that activity time would be done during the implementation of Integrated Health Post at the cadre's house to involve more participants. In addition, it was also agreed that this activity must comply with the health protocols.

3) Field Survey

This activity was initiated by surveying at the Arjasa Auxiliary Health Center at the Kemuning Lor village by assessing the policies and implementation in the Integrated Health Post during the Covid-19 period. The regional midwife strongly supported the stimulus community partnership program (PKMS).

4) Implementation of counseling and demonstration:

a) Counseling on the benefits of fish-based nutrition to prevent anemia in pregnant women

This activity was attended by pregnant women who checked in the Integrated Health Post at Kemuning Lor. They were very enthusiastic about listening to information about pregnancy and the effect of nutrition on pregnant women. Regional midwives also accompanied this activity. The activity began with data collection, followed by an examination of pregnant women. Then, counseling was given for 30 minutes. Cadres as movers in the Integrated Health Post were also implicated in assisting health workers in increasing knowledge among pregnant women.

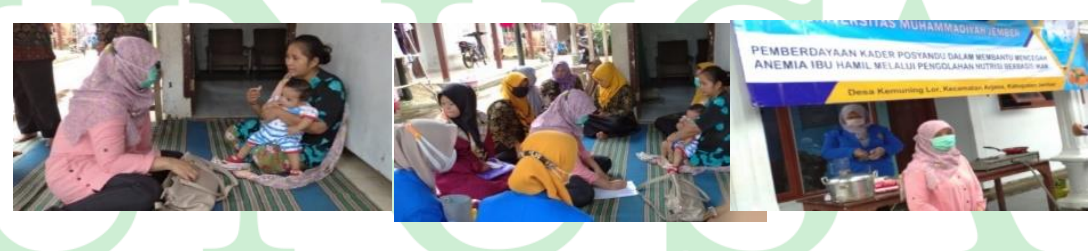

Figure 2. Counseling in cadres and pregnant women

b) Demonstration of Fish Nugget Processing 
The demonstration was carried out on cadres and pregnant women who come to the integrated health post. They were very enthusiastic about participating in the training activities. After the demonstration, they tried fish nuggets and said that the nuggets did not make the mother nauseous. They believed that pregnant women could consume it. The steps of fish nugget processing were as follows:

(1) Tools and materials : Tools used in this demonstration included scales, spoons, gas stoves, bowls, plastic, pots, pans, and blenders. The ingredients used were tuna or catfish meat 150 grams, one egg, one tablespoon cornstarch, one tablespoon wheat flour, one tablespoon tapioca flour, 150 grams white bread flour, 150 grams yellow bread flour, 0.25 grams powdered broth, 0.25 grams salt, one tsp sugar, 2-3 cloves of garlic, 50 grams carrots and 50 grams scallions.

(2) Process:

a) Mixed the fillet of cob or catfish with eggs, garlic, sugar, and salt, then blended in a blender.

b) Mixed the dough with flour, cornstarch, tapioca, white bread flour, powdered broth, pepper powder, carrots, and scallions, then stirred until smooth.

c) Put the dough on a banana leaf or plastic, then steamed it for 15 minutes

d) Cut the steamed dough and then dip it in a mixture of flour and yellow bread flour

e) the nuggets were packaged in plastic and then stored in the refrigerator at a temperature of $\pm 4^{\circ} \mathrm{C}$

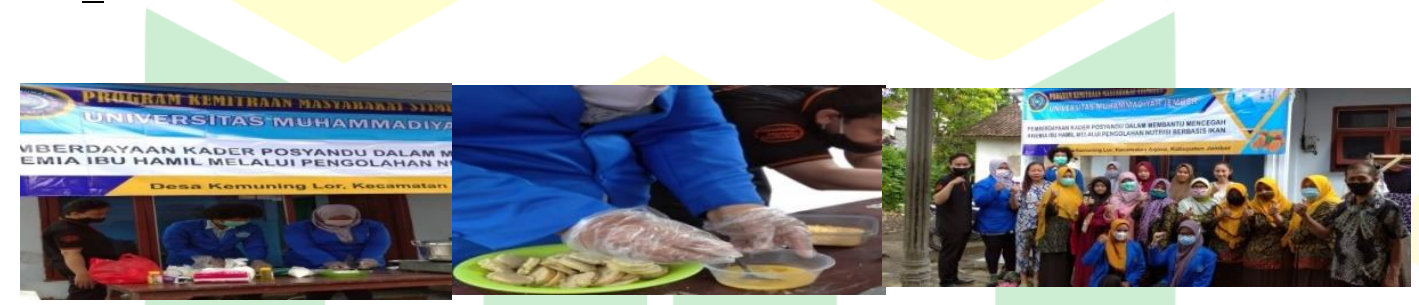

Figure 3. Demonstration of Fish Nugget Processing

The participants wanted to try fish nugget processing in their homes as a healthy snack for pregnant women. The ingredients used are cheap and easy to get. Thus, this activity is very beneficial for all participants. It can even be a new idea for a household business.

\section{CONCLUSION AND SUGGESTION}

The counseling and demonstration of fish nugget processing improve knowledge in Integrated Health Post cadres and pregnant women. Furthermore, it can prevent anemia in pregnant women. There should be support and participation from the local government for the sustainability of this activity.

\section{ACKNOWLEDGMENTS}

We want to thank the Integrated Health Post cadres at Kemuning Lor Village, Arjasa District, Jember Regency, and The Institute for Research and Community Service (LPPM) of the Muhammadiyah University of Jember, who have supported this activity.

\section{REFERENCES}

Badan Pusat Statistik, K. J. (2018) Kecamatan Arjasa dalam Angka 2018. Badan Pusat Statistik Kabupaten Jember.

Dewangga, V., Kamal, M. and Susanti, N. (2020) 'Pemberdayaan Karang Taruna Dalam Mengembangkan Desa Kemuning Lor Kecamatan Arjasa Sebagai Desa Wisata’, in Seminar Nasional Hasil Pengabdian Masyarakat, pp. 256-262. 
Didah, D. (2020) 'Peran dan Fungsi Kader Posyandu Di Wilayah Kerja Puskesmas Jatinangor', Jurnal Kebidanan Malahayati, 6(2), pp. 217-221. doi: 10.33024/jkm.v6i2.2306.

Gebreweld, A. and Tsegaye, A. (2018) 'Prevalence and Factors Associated with Anemia among Pregnant Women Attending Antenatal Clinic at St'. Ethiopia: Paul's Hospital Millennium Medical College, Addis Ababa. doi: 10.1155/2018/3942301.

Hidayat, R., Maimun, M. and Sukarno, S. (2020) 'Analisis Mutu Pindang Ikan Tongkol (Euthynnus affinis) dengan Teknik Pengolahan Oven Steam', Jurnal FishtecH, 9(1), pp. 21-33. doi: 10.36706/fishtech.v9i1.11003.

Ho, A., Flynn, A. C. and Pasupathy, D. (2016) 'Nutrition in pregnancy', Obstetrics, Gynaecology and Reproductive Medicine, 26(9), pp. 259-264. doi: 10.1016/j.ogrm.2016.06.005.

Kamaruddin, M. et al. (2019) 'Korelasi Antara Status Gizi Dan Kadar Hemoglobin Pada Kejadian Anemia Ibu Hamil Trimester Iii', Medika Alkhairaat : Jurnal Penelitian Kedokteran dan Kesehatan, 1(3), pp. 8288. doi: 10.31970/ma.v1i3.32.

M., Jusni and Amalia Sari, N. (2019) 'Persepsi dan Pengetahuan Mahasiswa Akademi Kebidanan Tahirah Al Baeti Terhadap Gizi Remaja', Medika Alkhairaat: Jurnal Penelitian Kedokteran dan Kesehatan, 1(3), pp. 114-118. doi: 10.31970/ma.v1i3.41.

Kamaruddin, M., Karlina, I. and Nurhayani, N. (2019) 'DESKRIPSI PENGETAHUAN DAN PEMAHAMAN MAHASISWA AKADEMI KEBIDANAN TAHIRAH AL BAETI TENTANG ANEMIA IBU HAMIL', Jurnal Medika Al Khairaat, 1(3), p. 5.

Koenig, M. D. (2017) 'Nutrient Intake During Pregnancy', JOGNN - Journal of Obstetric, Gynecologic, and Neonatal Nursing, 46(1), pp. 120-122. doi: 10.1016/j.jogn.2016.11.004.

Nafsiyah, I., Nurilmala, M. and Abdullah, A. (2018) 'Komposisi nutrisi ikan sidat Anguilla bicolor bicolor dan Anguilla marmorata', Jphpi, 21(3), pp. 504-512.

Nisa, J., Rahmanindar, N. and Harnawati, R. (2019) 'Peningkatan Persepsi Gizi Pada Remaja Dalam Upaya Pencegahan Kejadian Anemia Di Smk 1 Kota Tegal', Jurnal Pengabdian Masyarakat Progresif Humanis Brainstorming, 2(1), pp. 7-12. doi: 10.30591/japhb.v2i1.1277.

Oh, C., Keats, E. C. and Bhutta, Z. A. (2020) 'Vitamin and mineral supplementation during pregnancy on maternal, birth, child health and development outcomes in low-and middle-income countries: A systematic review and meta-analysis', Nutrients, 12(2). doi: 10.3390/nu12020491.

Septiyaningsih, R., Indratmoko, S. and Yunadi, F. D. (2020) 'Pemberdayaan Kader Posyandu Dalam Upaya Skrining Kehamilan Melalui Pemeriksaan Kehamilan Sederhana di Desa Menganti Kabupaten Cilacap Abstrak Angka Kematian Ibu ( AKI ) menjadi indikator penting kemajuan suatu bangsa dan merupakan bentuk indikator keberha', Jurnal Pengabdian Masyarakat Al-Irsyad, II(2), pp. 154-162.

Sugiartono, E., Mahanani, R. S. and K, B. P. Y. (2020) 'Peningkatan Ekonomi Msyarakat Melalui Pengembangan Usaha Keripik Singkong "JUMAIRI" Desa Kemuning Lor Kecamatan Arjasa Kabupaten Jember', in Seminar Nasional Hasil Pengabdian Masyarakat, pp. 81-84.

Suhat and Hasanah, R. (2014) 'Faktor-Faktor Yang Berhubungan Dengan Keaktifan Kader Dalam Kegiatan Posyandu (Studi Di Puskesmas Palasari Kabupaten Subang', Jurnal Kesehatan Masyarakat, 10(1), pp. 73-79.

Zulhaida Lubis et al. (2017) 'Biskuit Chohi Sebagai Alternatif Untuk Perbaikan Gizi Balita Dan Ibu Hamil Pada Masyarakat Nelayan Di Desa Percut Kecamatan Percut Sei Tuan', ABDIMAS TALENTA: Jurnal Pengabdian Kepada Masyarakat, 2(1), pp. 62-65. doi: 10.32734/abdimastalenta.v2i1.2200. 